\title{
Japan's tipping point
}

\author{
With changing demographics, a tight economy and increasing competition, Japan could \\ slide from the top ranks of research nations. Drastic action is needed.
}

n May last year, Japan's science and education ministry issued a white paper that sounded an alarm for science and technology: because of increasing international competition, especially from China, and a declining young work force at home, Japan might "be forced out of the ranks of major international players and will risk losing [its] current plentiful and stable lifestyle".

Policy-makers have long worked to keep Japan in the top class. Last October, in a timely reminder of Japan's potential, four scientists who were born and educated in Japan received Nobel prizes. But can Japan continue to produce large quantities of high-calibre science as its researchers age and science-hungry university students grow scarce?

The outlook is grim, if this year's white paper, released last month, is anything to go by. Between 1998 and 2007, the number of researchers in universities rose by $15 \%$, from 146,000 to 168,000 . But in the same period, the number of researchers younger than 37 years old shrank from 36,773 to 35,788 , and now only account for $21 \%$ of the total. The future is bleaker. The number of university students who want to study science and engineering plummeted from roughly 1 million in 1992 to around 630,000 in 2008.

Like its predecessors, the new white paper focuses on the possibility of invigorating the research community by increasing international exchange, recruiting women and encouraging young Japanese scientists. It should be possible to overcome Japan's famous cultural and language barriers and increase the flux of researchers across its borders. The RIKEN institutes do a pretty good job, and RIKEN's Functional Annotation of the Mouse cDNA project has been a shining example of how to coordinate an international project that continues to attract top foreigners to Japan.

\section{Foreign investment}

But that challenge is huge. After decades of extolling internationalization, only $10 \%$ of $\mathrm{PhDs}$ from Japanese universities go to people from other countries (compared with $42 \%$ in the United States and $41 \%$ in the United Kingdom). The percentage of foreign scientists at the country's universities and research institutes sits at a meagre $1.34 \%$.

Alarmingly, Japanese scientists are less keen to go abroad, forgoing the international experience that produced some of Japan's most creative minds. Although two of the four Nobel prizewinners had worked with US institutes, the number of researchers spending more than 3 months in a foreign laboratory has dropped from 7,118 in 1997 to 4,163 in 2006 . According to last month's white paper, only $2 \%$ of Japanese researchers had plans to work overseas. As international competition for scientific talent intensifies, Japan is closing in on itself.

Meanwhile, the struggle to encourage women in science, after years of effort, has produced only modest gains. The $12 \%$ of researcher posts held by women still places Japan near the bottom of the heap. Attitudes change slowly, and Japan is still a long way from fully tapping this resource.

Japan puts huge effort - at least on paper - into programmes to encourage young scientists. At least six ministries have such schemes. For instance, under the encouragement of the science and education ministry, 28 institutions have developed tenure-track systems that offer independence to younger scientists. And competitive grants for young scientists now contain about $30 \%$ towards indirect costs, which gives them more flexibility.

These plans are a promising start but it will take time to determine whether these movements will be able to level the top-heavy, deference-laden research structure currently in place. It doesn't help that young researchers will face a tightening job market as the science ministry reduces the money allocated to universities by $1 \%$ per year.

The country needs to experiment with aggressive policies. Initiatives such as the Kyoto University International Young Scientists Career Development Organization, which deliberately seeks to have one-third of the positions for young scientists filled by women and half by foreigners, should be duplicated and supported elsewhere.

Japan's dependence on domestic scientists and its need for fresh ideas
"How much longer can Japan afford to lose the talent that its system is either chewing up or simply not developing properly?" also justifies another radical investment in its longer term future: a $¥ 9.5$-billion (US\$100-million) science high school in Yokohama (see page 171). Other metropolitan centres should consider the benefits of such investment.

Overall Japan's science budget - at 3.61\% of its gross domestic product - puts Japan near the top of the expenditure league tables. But the share of government-funded research is low. A ¥270-billion gift, courtesy of the government's economic stimulus packages, will fund 30 projects over 5 years. This is a huge amount of money. The package is likely to boost applied research, but in the interests of Japan's longer-term research fitness, such a sum should be spent extending the life of competitive grants, supplying more of them and creating new, independent tenure-track positions for young researchers at universities.

With little hope for a massive influx of creative thinkers from outside, Japan needs to fix the system that frowns on giving professorships and other opportunities to young independent scientists. How much longer can Japan afford to lose the talent that its system is either chewing up or simply not developing properly?

In its chronic failure to provide sufficient incentives and support for young researchers' independence, Japan as a scientific power is marching right past its tipping point. 